\title{
Computational investigation of marine bioactive compounds against E6 oncoprotein of Human Papilloma Virus-HPV16
}

\author{
Pavithra Dhamodharan, Nirmaladevi Ponnusamy, Rajasree Odumpatta, Sajitha Lulu, Mohanapriya Arumugam* \\ Department of Biotechnology, School of Biosciences and Technology, Vellore Institute of Technology University, Vellore, Tamil Nadu, India.
}

\section{ARTICLE INFO \\ Article history: \\ Received on: 31/08/2017 \\ Accepted on: 13/03/2018 \\ Available online: 29/04/2018}

\section{Key words:}

Cervical cancer, E6

oncoprotein, Marine sponges,

Bioactive compounds,

Molecular Docking,

Salicylihalamide B.

\begin{abstract}
Objective: Cervical cancer is the most leading cause of mortality and morbidity in women. Most of these are caused by human papilloma virus (HPV) which are sexually transmitted. Among 200 HPV types, high-risk HPV16 persists in humans and results in precancerous lesions and cervical cancer. The viral E6 oncoprotein which is necessary for malignant conversion of HPV 16 is used as the potential target for the inhibition of HPV infection. The present study aims to investigate the inhibitory activities of the seventy-four bioactive compounds from different marine organisms against the viral E6 oncoprotein of HPV16 using computational techniques. Methods: Virtual screening technique has been applied to identify the potent bioactive compounds against E6 oncoprotein of HPV16 using Molinspiration and is subjected to drug-likeliness assessment using the Molsoft server. Molecular docking was carried out for E6 protein (4XR8) with selected hits obtained from virtual screening method and their binding energies were determined. Further Molecular Dynamic Simulation (MDS) studies of the obtained protein-bioactive inhibitor complex were performed to analyze the stability and conformation. Results and Conclusion: Four potential hits were identified from virtual screening and finalized against HPV16. Molecular docking studies revealed Salicylihalamide B from Haliclona species has shown the better interaction with E6 oncoprotein and gives the best binding energy of $-8.92 \mathrm{Kcal} / \mathrm{mol}$. The MDS studies inferred that the complex was found to be steady after $40 \mathrm{~ns}$. As an outcome, Salicylihalamide B plays a promising role against E6 protein of HPV16 and hence can act as a template for further studies on cervical cancer drug candidates.
\end{abstract}

\section{INTRODUCTION}

Human papilloma virus codes for $5.2 \%$ of all cancers worldwide. Cervical cancer is one of the significant mortality amongst women due to human papilloma virus infection. Human papilloma virus (HPVs) are small, circular double-stranded DNA viruses with a genome of approximately $8 \mathrm{~kb}$ (White et al., 2012). HPV comprise more than 200 types of infections, among which the high-risk HPV types 16 and 18 are the main cause and account for about $70 \%$ of cervical cancer. One HPV type (HPV 16) emerges as profoundly connected with malignancies at a few distinctive anatomical locations such as cervix, penis, anus, oropharynx, esophagus (Liyanage et al., 2013) and bladder (Husain et al., 2009;

\section{"Corresponding Author}

Mohanapriya Arumugam, Department of Biotechnology, School of Biosciences and Technology, Vellore Institute of Technology University, Vellore,Tamil Nadu,India.E-mail: mohanapriyaa@vit.ac.in
Li et al., 2011). HPV type 16 is the most oncogenic type, followed by type 18 as the next most virulent (Hoory et al., 2008). HPV16 belongs to the genus of Alpha-papilloma virus and a member of species 9. The genome organization of HPV16 is organized into three regions: an early region (E), a late region (L), and a noncoding long control region (LCR). The early region encodes six non- structural proteins: E1, E2, E4, E5, E6, and E7. Late region encodes two structural proteins: L1 and L2. The non-structural proteins E1, E2, E4, and E5 proteins are required for viral DNA replication, the E6 and E7 proteins cooperate to transform and immortalize cells, and the L1 and L2 proteins are needed for the production of viral particles (Ledwaba et al., 2004; Munger et al., 2004). Among the non-structural protein products, E6 protein plays a role in the induction and maintenance of cellular transformation. The HPV 16 E6 protein consists of 151 amino acids and has a molecular weight of $18 \mathrm{kDa}$ with two zinc fingers and also has a high content of $\alpha$-helical and $\beta$-sheet secondary structures (Tungteakkhun et al., 2008). 
There are different interacting partners of E6 protein, the first and most vital cellular target of E6 protein is p53. HPV E6 oncoprotein interacts with several other cellular targets such as E6-AP, p53, CBP/P300. The importance of p53mediated apoptosis has been recognized in terms of maintaining homeostasis and preventing neoplastic transformation. E6 forms a ternary complex with p53 and E6 associated protein (E6AP) resulting in the degradation of p53 via ubiquitination pathway (Huibregtse et al., 1991). E6 also interacts with transcriptional co-activators $\mathrm{CBP} / \mathrm{P} 300$ is directly independent of proteins known to bind the co-activators, such as p53 (Patel et al., 1999). The E6 protein binds to three domains of $\mathrm{CBP} / \mathrm{P} 300$ and affects the transcriptional activity of the co-activators. High-risk HPV E6 binds to E6-AP (E6 Associated Protein) inside its N-terminal substrate recognition domain (Huibregtse et al., 1993a), and formation of a stable E6-E6AP complex precedes association with p53, thereby redirecting the substrate specificity of E6AP towards p53 (Huibregtse et al., 1993b). Hence E6AP also plays an essential role in E6 directed degradation of $\mathrm{p} 53$. Compared to other cellular targets, Thomas et al. (1999) evidenced that p53 activities is controlled in association with E6-AP and E6* proteins and leads to the replication of the virus and undoubtedly an E6-p53 association gives fundamental importance in the pathogenesis of HPV and represents as an important therapeutic target for many important human cancers (Thomas et al., 1999).

Marine sponges have been positioned at the top because of the discovery of bioactive compounds with potential pharmaceutical applications. Specialists in the field of natural products chemistry propose that sponges have the potential to provide future drugs against important diseases such as a range of viral diseases, malaria, inflammations, immunosuppressive diseases and various malignant neoplasms (Alcaraz et al., 2006; Molinski et al., 2009; Simmons et al., 2005; Gordaliza et al., 2010). Sponges produce various natural components and metabolites by isolation and screening of bioactive substances lead to the discovery of several chemicals with antiviral properties (Sipkema et al., 2005). Therefore, marine sponges are considered as a prosperous source of chemical diversity and health benefits for developing drug candidates, cosmetics, nutritional supplements, and molecular probes that can be supported to enhance the healthy lifespan of humans (Perdicaris et al., 2013). Sponges of the genus Haliclona are noticeable for producing a variety of secondary metabolites, most commonly bioactive alkaloids. Our study focuses on the in silico identification of potential bioactive inhibitors from marine algal sources against cervical cancer which is caused by HPV16 E6 oncoprotein.

\section{MATERIALS AND METHODS}

\section{Retrieval of E6 protein structure}

The three-dimensional structure of E6 protein was retrieved from PDB and hence we considered the entry 4XR8 as a target for marine algal bioactive compounds. In contrast to all other entries of E6 protein, 4XR8 shows larger position availability in X-ray method with a resolution of $2.25 \AA$ (http://www.uniprot. org/uniprot/P03126). The RCSB PDB (Research Collaboratory for Structural Bioinformatics Protein Data Bank) is a repository for three-dimensional structural information of large biomolecules such as proteins and nucleic acids.

\section{Construction of ligand dataset from marine sources}

Among marine invertebrates, marine sponges from phylum Porifera is the most prevailing group responsible for discovering a huge number of natural products, that have been used as a template to develop therapeutic drugs. These natural products have a wide range of therapeutic properties including antimicrobial, antioxidant, antihypertensive, anticoagulant, anticancer, anti-inflammatory, wound healing and immune modulator, and other medicinal effects (Perdicaris et al., 2013). The bioactive compounds from various marine organisms such as different types of algae, sponge, bacteria which can act against the viral protein E6 were collected from the literature. 74 bioactive compounds from marine organisms were collected which forms the ligand dataset. PubChem database provides information about the chemical compounds, structure and their biological activities. Structure Data File (SDF) of the bioactive compounds was retrieved from PubChem database and converted to PDB format using OpenBabelGUI (O’Boyle et al., 2011). Accordingly, compound structures were saved in MOL format, later it is converted to PDB using OpenBabelGUI.

\section{Virtual Screening of bioactive compounds}

74 bioactive compounds from marine sources were involved in this study (Michalak et al., 2015; Simmons et al., 2005; Jimenez et al., 2009; Hartog et al., 1999; Adams et al., 2013; Jiao et al., 2011; Pal et al., 2014; Plaza et al., 2010; Francavilla et al., 2012; Kakinuma et al., 2001; Pereira et al., 2012; Saeidnia et al., 2014; Asgharpour et al., 2015; Yu et al., 1981; Panayotova et al., 2013; Michiels et al., 2011; Karsten et al., 1998; Groniger et al., 2000; Gupta et al., 2011; Apt et al., 1995; Sajilata et al., 2008; GarcíaVilas et al., 2016; Krohn, 2007; Manam et al., 2005; Domozych et al., 2012; Murakami et al., 2001; Isbrucker et al., 2003; Oliveira et al., 2012; Ponder et al., 2011; Aoki et al., 2004). Virtual screening offers a computational prediction of binding affinity for a large set of compounds. Screening of large libraries of compounds can be performed using docking. The final outcomes are positioned to propose basic theories of how the ligands hinder the target, a key objective in lead optimization. Virtual screening technique is used to construct the libraries of the marine bioactive compounds and also filters out the relevant bioactive compounds against the viral protein E6 using two softwares such as Molinspiration and Molsoft. All the bioactive compounds were optimized using Argus lab 4.0.1 using AM1 (Austin model 1) force field (http://www. arguslab.com/arguslab.com/ArgusLab.html).

\section{Physicochemical and drug-likeness property prediction}

Molinspiration tool, (http://www.molinspiration. com/cgi-bin/properties) is used in this study to calculate the molecular properties of bioactive compounds. Lipinski's filter includes properties like molecular weight, ClogP, polar surface area, number of hydrogen bond donors and acceptors, number of atoms, violations, rotational bonds, and volume. The Druglikeness score of the bioactive compounds was predicted using Molsoft software (http://molsoft.com/mprop/). The qualitative concept drug-likeness reveals information about how a drug responds to components like bioavailability and also checks the toxicity of the compound. Theoretically, a drug-like substance has a log $\mathrm{P}$ range of -0.4 to 5.6 , molecular weight 180 to 500 Daltons, 
molar refractivity of $40-130$, which is related to the volume and molecular weight of the molecule, also it has 20-70 atoms and follow other Lipinski's rules (Ghose et al., 1999).

\section{Molecular docking studies}

Molecular docking is the best way to estimate the interaction between two molecules (Arumugam et al., 2013). Thus, to refine the retrieved hits from the previous analysis, docking was performed for all the hit compounds with the target protein E6. AutoDock is an automated docking procedure for predicting the interaction of ligands with bio-macromolecular targets. The four Bioactive compounds such as ascorbic acid, frigocyclinone, salicylihalamides A and B sieved out from the virtual screening technique were docked against the viral protein E6 using AutoDock tools 4.2 (Morris et al., 2009). Hydrogen atoms are added to the protein structure and Kollman charges are added to the protein and saved in .pdbqt format. After detecting the root, the ligand files are saved in .pdbqt format. A Lamarckian genetic algorithm is used as a docking parameter to find globally optimized conformation. The grid box dimension was set to $60 \times 60 \times 60$ and for the remaining parameter default settings were applied. At the end of a docking with multiple runs, a cluster analysis was performed (Sundarrajan et al., 2014). The bioactive compounds were analyzed based on their binding energy values.

\section{Molecular dynamics simulation studies}

The molecular dynamics simulation (MDS) calculates the stability of the protein-ligand complex. The docked protein-ligand complex obtained from Autodock program was considered as starting model for MDS. It is used to investigate the thermodynamics of biological macromolecules and their complexes. MDS of the protein-ligand complex with lowest binding energy was performed using GROMACS 4.5.5 (Groningen Machine for Chemical Simulations). The protein topology file was prepared using GROMOS96 43a1 force field (Schuler et al., 2001). Ligand topology file and force field parameter file were prepared using PRODRG server (Schüttelkopf et al., 2004). The whole system was subjected to $50 \mathrm{~ns}$ MDS at $300 \mathrm{~K}$ temperature and 1 bar pressure. The potential energy fluctuations, Root mean square deviation of alpha carbon atoms, Root mean square fluctuation and radius of gyration were monitored.

\section{RESULTS AND DISCUSSION}

\section{Role of E6 protein in HPV16}

E6 protein is a major transforming protein and also acts as a critical factor in cervical carcinogenesis of HPV16. E6 binds with E6AP ubiquitin-protein ligase and inactivates P53 via proteasome degradation pathway thereby DNA damage and chromosomal instabilities occur which leads to cell proliferation and cancer development in humans. Therefore, to prevent this we manually selected 74 marine bioactive compounds from literature sources which can compete with E6 protein.

\section{Virtual screening of bioactive compounds from marine sources}

74 biologically active compounds from different marine organisms involved in this study have been listed in Table 1. The
2D structure file is given in S. Figure 1. Virtual screening involves evaluation of a large number of small compounds based on their several molecular properties, using computational methods. We subjected our bioactive compounds to virtual screening specifically to calculate physicochemical properties and drug likeliness score using Molinspiration and Molsoft softwares. The SMILES (Simplified Molecular-Input Line-Entry System) notation of the bioactive compounds were used to calculate the molecular properties and drug likeliness score. The compounds which obey Lipinski's rule were further screened using molecular docking and simulation studies. Lipinski's rule components which are molecular weight $<500, \log \mathrm{P}$ not greater than 5 , Hydrogen bond donors not more than 5 and Hydrogen bond acceptors not more than 10 , number of atoms from 20 to 70,10 or fewer rotatable bonds. The properties like milogP, TPSA, number of atoms, hydrogen bond donors and acceptors, molecular weight and rotational bonds of the marine bioactive compounds were predicted (Table 2). 74 bioactive compounds were first subjected to molinspiration to check the physicochemical characteristics of the compound and as a result, we filtered 24 bioactive compounds which obey the Lipinski's rule. These compounds were further subjected to drug-likeness score prediction using molsoft. Four compounds show above 0.5 drug-likeness score was selected as a good drug candidate and proceeds for further studies. In Molsoft software also the SMILES notation is used to check the druglikeness score of the compounds. The drug-likeness score of the potential bioactive compounds is listed in Table 3. As an outcome of the virtual screening technique, we finalized four bioactive compounds such as Ascorbic acid from Ascophyllum Nodosum, Frigocyclinone from Streptomyces Griseus, Salicylihalamides A and B from Haliclona Species may have potential to act against the viral protein E6 and further investigated for molecular docking studies.

\section{Molecular docking studies of E6 protein with bioactive inhibitors}

Elucidation of ligand binding mechanism in the essential phase to achieve selective and potent drugs for any target. Therefore, the four bioactive compounds (Ascorbic acid, Frigocyclinone, Salicylihalamides A and B) were docked separately into the binding site of the target protein E6 using AutoDock 4.2. The Protein-ligand interaction binding energies give a better understanding about how well the drugs bind to the E6 protein molecule. Among the four bioactive compounds, Salicylihalamide B from Haliclona Species had shown the better interaction with E6 protein with a binding energy of $-8.92 \mathrm{Kcal} / \mathrm{mol}$. Ascorbic acid (-3.82), Frigocyclinone (-8.01), Salicylihalamide A ( -8.76$)$ have lesser binding energy values than Salicylihalamide B and their binding site residues were identified using Pymol (Table 4). The four bioactive compounds interacted with E6 protein and formed a complex which was visualized using pymol and their 2D interaction patterns were identified using Discovery studio visualizer (Figure 1). E6 protein (green) represented as a surface model and the ligands are represented as ball and stick model. The residues interacting with ascorbic acid form hydrogen bond interaction with aliphatic amino acids LEU99, LEU110 and hydrophilic amino acid ASP49. It also forms vanderwaals interaction with aliphatic amino acids 
PRO112, CYS111, PRO109, ILE101, LYS115, LEU100 and carbon-hydrogen bond interaction with LEU110 (Figure 1e). Frigocyclinone forms hydrogen bond interaction with aromatic group TRP132 and aliphatic group LEU100, vanderwaals interaction with aliphatic groups LEU67, GLY107, LEU50, ILE101, SER74, GLY130, LEU99, Carbon-Hydrogen bond with SER71, strong hydrophobic pi-sigma interaction with LEU100 and ARG131 and hydrophobic pi-alkyl interaction with ARG102 and ARG131 (Figure 1f). Salicylihalamide A forms hydrogen bond interaction with hydrophilic ARG102 and hydrophobic CYS51, vanderwaals interaction with GLY130, LEU100, VAL53,
PHE45, TYR32, SER74, SER71, GLN107, ARG131, ILE101, hydrophobic pi-sigma interaction with VAL62, hydrophobic alkyl interaction with LEU67 and pi-alkyl interaction with LEU50, TRP132 (Figure 1g). Salicylihalamide B forms hydrogen bond interaction with ARG102 and CYS51, vanderwaals interaction with both aliphatic and aromatic amino acid groups VAL53, PHE45, TYR32, GLN107, SER71, SER74, ARG131, TRP132, GLY130, hydrophobic Alkyl interaction with LEU67 and LEU100 and strong pi-alkyl interaction with aliphatic groups VAL62 and LEU50 (Figure 1h).

Table 1: Dataset table - Seventy-four bioactive compounds from marine sources used for the study.

\begin{tabular}{|c|c|c|c|c|}
\hline Bioactive Compounds & Compound Family & Algae & Algal Family & References \\
\hline Docosahexaenoic acid & PUFA* & Schizotrychium & Thraustochytriacea & Hartog et al. (1999) \\
\hline Eicosapentaenoic acid & PUFA* & Porphyridium cruentum & Porphyridiophyceae & Asgharpour et al. (2015) \\
\hline Beta carotene & Carotenoids & Dunaliella salina & Dunaliellaceae & Hartog et al. (1999) \\
\hline Lutein & Carotenoids & Muriellopsis & Chlorophyceae & Hartog et al. (1999) \\
\hline Astaxanthin & Keto carotenoid & Hematococcus pluvialisis & Haematococcaceae & Hartog et al. (1999) \\
\hline Griffithsin & Lectin & Griffithsia & Wrangeliaceae & Adams et al. (2013) \\
\hline Fucoidan & Sulfated polysaacharide & Fucus vesciculosis & Fucaceae & Jiao et al. (2011) \\
\hline Lambda carrageenan & Sulfated polysaacharide & Gigartina & Gigartinaceae & Jiao et al. (2011) \\
\hline Phloroglucinol & Polyphenol & Ecklonia species & Lessoniaceae & Michalak et al. (2015) \\
\hline Phycoerythrobilin & Phycobiliproteins & Callithamnion roseum & Callithamniaceae & Yu et al. (1981) \\
\hline Dictyol C & Diterpenes & Dictyota ciliolate & Dictyotaceae & Michalak et al. (2015) \\
\hline Dictyol H & Diterpenes & Dictyota ciliolate & Dictyotaceae & Michalak et al. (2015) \\
\hline Alpha tocopherol & vitamin $\mathrm{E}$ & Ulva rigida & Ulvaceae & Panayotovo et al. (2013) \\
\hline Ascorbic acid & Vitamin C & Ascophyllum Nodosum & Fucaceae & Michiels et al. (2011) \\
\hline Beta glucans & Polysaacharide & Laminaria Digitata & Laminariceae & Michalak et al. (2015) \\
\hline Laminarin & Polysaacharide & laminaria species & Laminariceae & Michalak et al. (2015) \\
\hline Palythine & Mycosporine-like amino acid & Chaetomorpha aerea & Cladophoraceae & Karsten et al. (1998) \\
\hline Shinorine & Mycosporine-like amino acid & Gelidium latifolium & Gelidiaceae & Groniger et al. (2000) \\
\hline Dolabellanes & Diterpenes & Dictyota ciliolate & Dictyotacaea & Gupta et al. (2011) \\
\hline Fucosterol & Sterols & Laminaria species & Laminariceae & Pal et al. (2014) \\
\hline Desmosterol & Sterols & Palmaria species & Palmariaceae & Pal et al. (2014) \\
\hline Agar & Sulfated polysaacharide & Gracilaria species & Gracilariaceae & Pal et al. (2014) \\
\hline Fucoxanthin & Carotenoid & Macrocystis pyrifera & Laminariaceae & Apt et al. (1995) \\
\hline Zeaxanthin & Carotenoid & Microcystis aeruginosa & Microcystaceae & Sajilata et al. (2008) \\
\hline Dolastatin 15 & Linear peptide & Dolabella auricularia & Aplysiidae & Simmons et al. (2005) \\
\hline E7389 & Macrocyclic polyether & Halichondria okadai & Halichondriidae & Simmons et al. (2005) \\
\hline Discodermolide & Lactone & Discodermia dissolute & Theonellidae & Simmons et al. (2005) \\
\hline LAF-389 & $\varepsilon$-Lactam peptide derivative & Jaspis digonoxea & Ancorinidae & Simmons et al. (2005) \\
\hline Curacin A & Thiazole lipid & Lyngbya majuscula & Oscillatoriaceae & Simmons et al. (2005) \\
\hline DMMC & Cyclic depsipeptide & Lyngbya majuscula & Oscillatoriaceae & Simmons et al. (2005) \\
\hline Salinosporamide A & Bicyclic $\lambda$-lactam- $\beta$ lactone & Salinospora species & Micromonosporaceae & Simmons et al. (2005) \\
\hline Laulimalide & Macrolide & Cacospongia mycofijiensis & Thorectidae & Simmons et al. (2005) \\
\hline Eleutherobin & Diterpene glycoside & Eleutherobia species & Alcyoniidae & Simmons et al. (2005) \\
\hline Sarcodictyin A & Diterpene & Sarcodictyon roseum & Clavulariidae & Simmons et al. (2005) \\
\hline
\end{tabular}




\begin{tabular}{|c|c|c|c|c|}
\hline Peloruside A & Macrocyclic lactone & Mycale hentscheli & Mycalidae & Simmons et al. (2005) \\
\hline Salicylihalamide A & Polyketide & Haliclona species & Chalinidae & Simmons et al. (2005) \\
\hline Salicylihalamide B & Polyketide & Haliclona species & Chalinidae & Simmons et al. (2005) \\
\hline Thiocoraline & Depsipeptide & Micromonospora marina & Micromonasporaceae & Simmons et al. (2005) \\
\hline Ascididemin & Aromatic alkaloid & Didemnum species & Didemnidae & Simmons et al. (2005) \\
\hline Lamellarin D & Pyrrole alkaloid & Lamellaria species & Velutinidae & Simmons et al. (2005) \\
\hline Dictyodendrin & Pyrrolocarbazole derivatives & Dictyodendrilla verongiformis & Dictyodendrillidae & Simmons et al. (2005) \\
\hline ES-285 (Spisulosine) & Alkyl amino alcohol & Mactromeris polynyma & Mactridae & Simmons et al. (2005) \\
\hline Aeroplysinin I & Alkaloid & Aplysina aerophoba & Aplysinidae & Jimenez et al. (2009); Garcia-vilas et al. (2016) \\
\hline Aureoverticillactam & Macrocyclic lactam & Streptomyces aureoverticillatus & Streptomycetaceae & Jimenez et al. (2009) \\
\hline Bonactin & Macrotetrolide antibiotic & Streptomyces species & Streptomycetaceae & Jimenez et al. (2009) \\
\hline Caprolactones & Lactone & Streptomyces species & Streptomycetaceae & Jimenez et al. (2009) \\
\hline Chandrananimycin & Benzoxazines & Actinomadura species & Thermomonosporaceae & Jimenez et al. (2009) \\
\hline Diazepinomicin & Alkaloid & Micromonospora species & Micromonosporaceae & Jimenez et al. (2009) \\
\hline Frigocyclinone & Angucyclinone antibiotic & Streptomyces griseus & Streptomycetaceae & Jimenez et al. (2009) \\
\hline Glaciapyrrole C & Pyrrolosesquiterpenes & Streptomyces species & Streptomycetaceae & Jimenez et al. (2009) \\
\hline Helquinoline & Tetrahydroquinoline antibiotic & Janibacter limosus & Intrasporangiaceae & Jimenez et al. (2009) \\
\hline Himalomycin A & Peptide antibiotic & Streptomyces Parvulus & Streptomycetaceae & Jimenez et al. (2009); Krohn et al. (2007) \\
\hline Himalomycin B & Peptide antibiotic & Streptomyces Parvulus & Streptomycetaceae & Jimenez et al. (2009); Krohn et al. (2007) \\
\hline Komodoquinone A & Anthracycline & Streptomyces species & Streptomycetaceae & Jimenez et al. (2009) \\
\hline Lajollamycin & $\begin{array}{l}\text { Nitro-tetraene spiro- } \beta \text {-lactone- } \lambda \text { - } \\
\text { lactam antibiotic }\end{array}$ & Streptomyces nodosus & Streptomycetaceae & Jimenez et al. (2009); Manam et al. (2005) \\
\hline Marinomycin B & Antibiotics & Marinispora & Marine actinomycete & Jimenez et al. (2009) \\
\hline MKN-349A & Cyclic tetrapaptide & Nocardiopsis species & Nocardiopsaceae & Jimenez et al. (2009) \\
\hline Trioxacarcin & Antibiotics & Streptomyces species & Streptomycetaceae & Jimenez et al. (2009) \\
\hline Phytosterols & Steroids & Dunaliella Tertiolecta & Dunaliellaceae & Francavilla et al. (2012) \\
\hline Glutathione (GSH) & Antioxidant & Ishige okamurai & Phaeophyta & Kakinuma et al. (2001) \\
\hline Gamma-linolenic acid & PUFA & Codium species & Chlorophyta & Pereira et al. (2012) \\
\hline Beta-sitosterol & Sterol & Gracilaria salicornia & Gracilariaceae & Saeidnia et al. (2014) \\
\hline Xylan & Polysaacharide & Ulvales & Ulvophyceae & Domozych et al. (2012) \\
\hline Phytol & Diterpene alcohol & Synechocystis species & Merismopediaceae & Plaza et al. (2010) \\
\hline Palmitoleic acid & Monounsaturated Fatty acid & Synechocystis species & Merismopediaceae & Plaza et al. (2010) \\
\hline Squalamine & Aminosteroid & Squalus acanthias & Squalidae & Simmons et al. (2005) \\
\hline Cemadotin & Linear peptide & Dollabella auricularia & Aplysiidae & Simmons et al. (2005) \\
\hline Soblidotin & Linear peptide & Dollabella auricularia & Aplysiidae & Simmons et al. (2005) \\
\hline Agosterol A & Steroid & Spongia species & Spongiidae & Jimenez et al. (2009); Murakami et al. (2001) \\
\hline Dictyostatin-1 & Polyketide & Spongia species & Spongiidae & Jimenez et al. (2009); Isbrucker et al. (2003) \\
\hline Laurenditerpenol & Diterpene & Laurencia intricata & Rhodomelaceae & Jimenez et al. (2009); Oliviera et al. (2012) \\
\hline Lissoclinolide & Fatty acid & Ascidian & Ascidiacea & Jimenez et al. (2009) \\
\hline Neoamphimedine & Alkaloid & Xestospongia species & Petrosiidae & Jimenez et al. (2009); Ponder et al. (2011) \\
\hline Smenospongorine & Seskviterpene & Dactylospongia elegans & Thorectidae & Jimenez et al. (2009); Aoki et al. (2004) \\
\hline
\end{tabular}

*PUFA- Polyunsaturated fatty acid. 

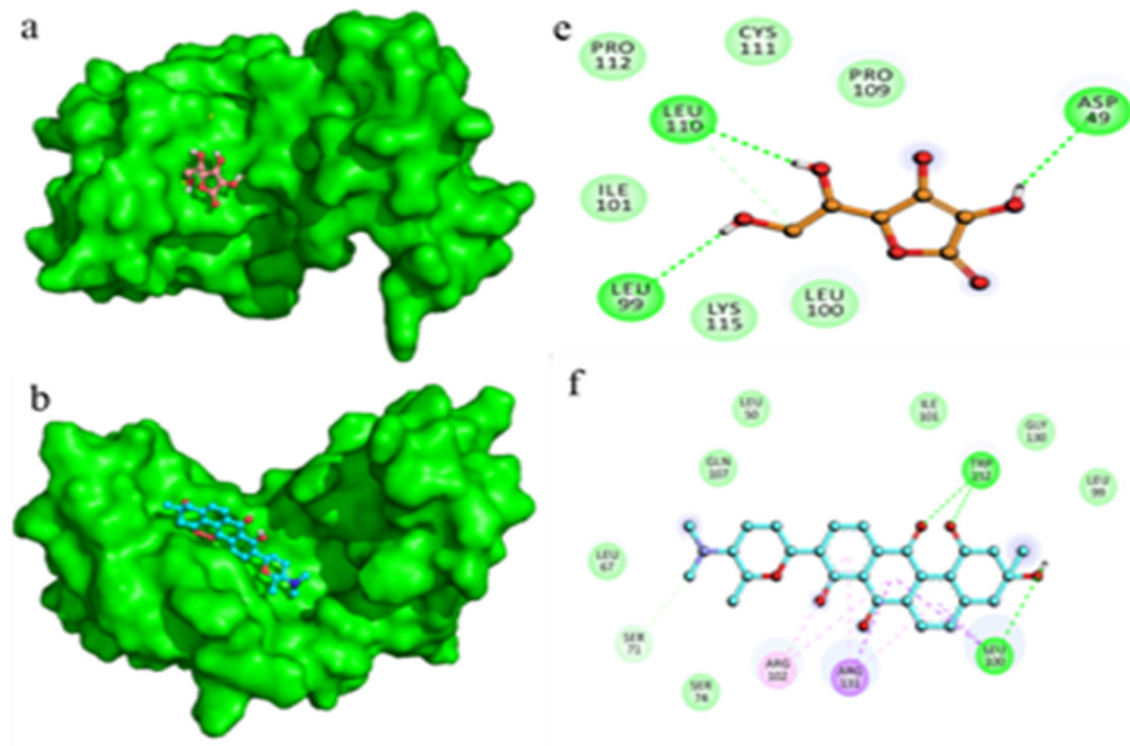

f
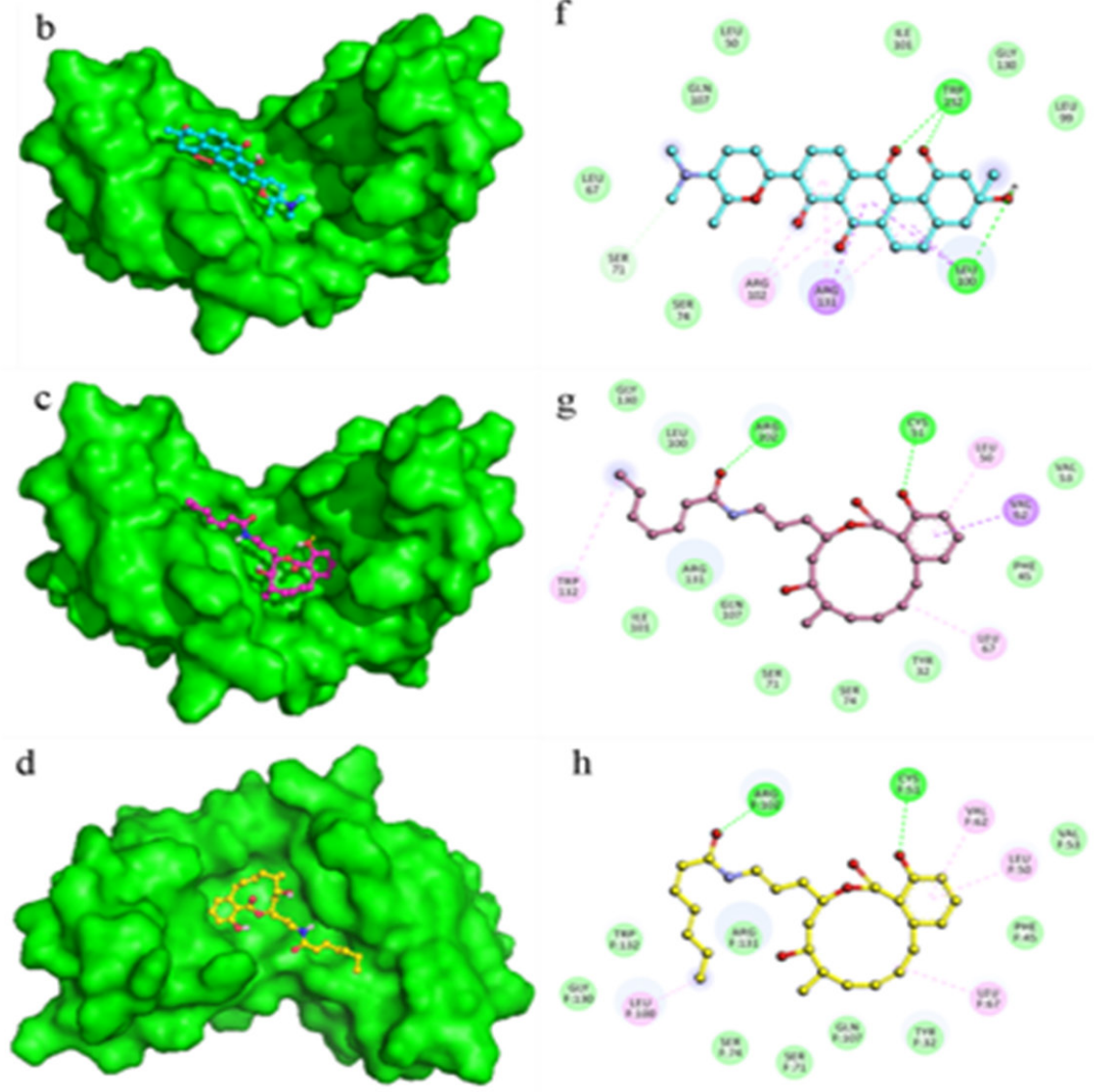

h

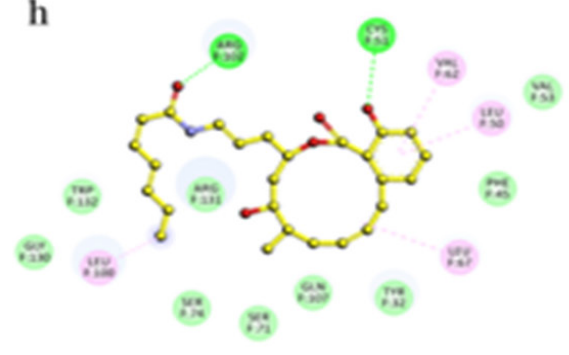

Hidroges bosd

P) Signa insoctioa

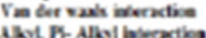

Carbea Bydvograbeal

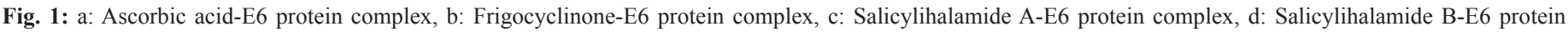
complex, e-h: 2D interaction pattern of four ligands with E6.

Table 2: Molecular properties of Bioactive compounds predicted using Molinspiration property calculator.

\begin{tabular}{|c|c|c|c|c|c|c|c|c|c|c|}
\hline S. No & Bioactive Compounds & miLogP & TPSA & Atoms & MW & \#ON & \#OHNH & \#Violations & \#ROTB & Volume \\
\hline 1 & Ascorbic acid & -1.4 & 107.22 & 12 & 176.12 & 6 & 4 & 0 & 2 & 139.71 \\
\hline 2 & Frigocyclinone & 3.62 & 104.14 & 34 & 463.53 & 7 & 2 & 0 & 2 & 418.12 \\
\hline 3 & Salicylihalamide A & 4.32 & 95.86 & 32 & 439.55 & 6 & 3 & 0 & 6 & 425.87 \\
\hline 4 & Salicylihalamide B & 4.32 & 95.86 & 32 & 439.55 & 6 & 3 & 0 & 6 & 425.87 \\
\hline
\end{tabular}

miLogP: $\log$ P (partition coefficient); TPSA: topological polar surface area; MW: Molecular weight; \#ON: number of hydrogen bond acceptors; \#OHNH: number of hydrogen bond donors; \#ROTB: number of rotational bonds. 
a)

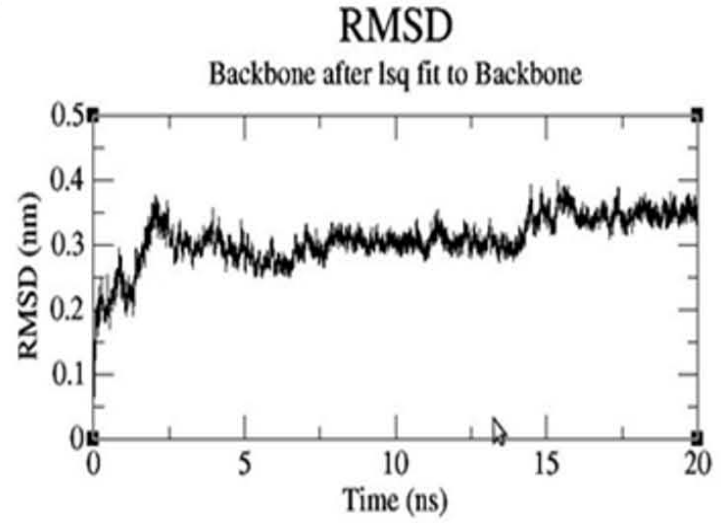

c)
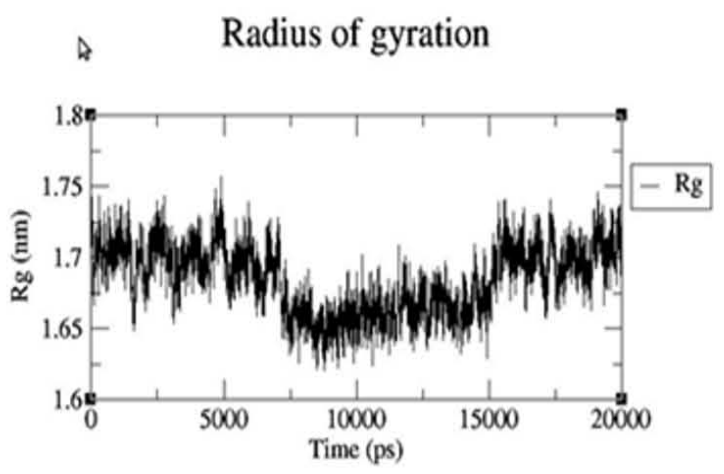

b)

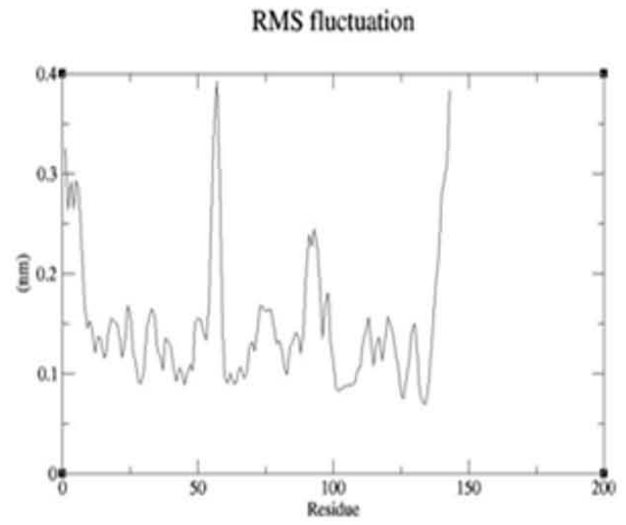

d)

\section{Gromacs Energies}

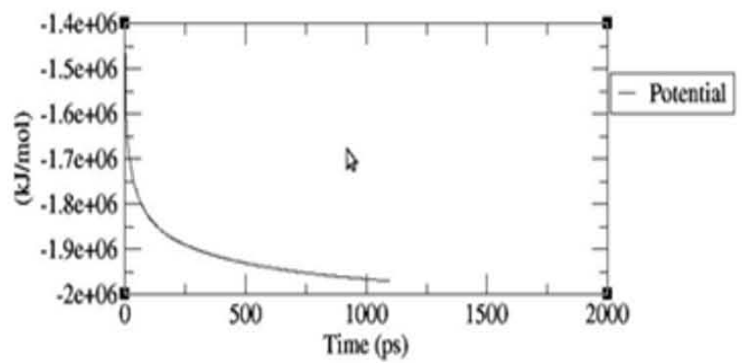

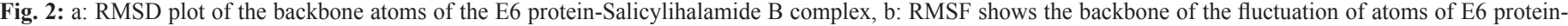
Salicylihalamide B complex, c: Radius of gyration of the protein has an average value at $1.74 \mathrm{~nm}$, d: Potential energy plot depicting the stability of the protein.

Table 3: Druglikeness prediction of bioactive compounds using Molsoft software.

\begin{tabular}{ccc}
\hline S. No & Bioactive Compounds & Druglikeness score \\
\hline 1 & Ascorbic acid & 0.84 \\
2 & Frigocyclinone & 0.93 \\
3 & Salicylihalamide A & 1.01 \\
4 & Salicylihalamide B & 1.01 \\
\hline
\end{tabular}

Interacting residues such as LEU100, TRP132, SER74, ARG102, LEU50 were found in all the docked complexes. The presence of residues at their respective positions are important for the binding of E6 protein. A group of arginine residues forms the rim cap over the E6 helix groove and plays a remunerative role in the binding and recognition of small molecules (Rietz et al., 2016). The aromatic group of tryptophan is found to involve in the pi-alkyl stacking interaction. The rim arginine ARG102 forms a hydrogen bond with Salicylihalamide B. TRP132 and ARG131 found to contribute to the interaction through vanderwaal's forces and lies in the C-terminal region of the E6 protein. As an outcome, Salicylihalamide B gives the best binding interaction pattern with E6 protein and also it may act as a lead molecule to compete with E6-E6AP complex and prevents its activation.
The Salicylihalamide B and E6 protein complex are then further validated for its stability using molecular dynamic simulation studies.

\section{Molecular dynamics and simulation analysis}

In order to examine the conformational stability, MDS was performed. From molecular docking studies, Salicylihalamide B - HPV16 E6 protein complex was subjected to MDS studies. GROMACS -4.5 .5 version is used to check the stability and the compactness of the complex. GROMOS96 43a1 forcefield was used for E6 protein. GROMOS87/GROMACS file with polar/Aromatic hydrogens is used as drg.gro file and the ligand topology file was used as drg.itp file. The lowest binding energy conformation was taken as initial conformation and solvated using SPC (single point charge) water molecule and neutralized by adding chlorine ions. Finally, 50 ns MD simulation was performed for the E6 Protein-Salicylihalamide B complex and the results were monitored. The entire system remained steady all through the MD simulation process. Various trajectory analysis like potential energy, RMSD, and RMSF of the backbone atoms, radius of gyration of the protein was monitored and they were analyzed to interpret the convergence, fluctuations and the stability of the 
protein-ligand complexes. RMSD analysis shows the Proteinligand complex exhibits numerous smaller peaks, and at $40 \mathrm{~ns}$ it started to converge and attained stability (Figure 2a). The protein structural flexibility during the simulation process was noticeable from the small drifts observed in the RMSD plot. The dynamic stability of the Protein-ligand complex was also determined based on the root mean square fluctuation which reflects the mobility of the residues around its mean position. RMSF shows major fluctuations at the residues 75,110 and 130 and minor fluctuations in the residues 30, 60 and 80 (Figure $2 \mathrm{~b}$ ). The radius of gyration maintains the compactness of protein at $1.75 \mathrm{~nm}$ (Figure $2 \mathrm{c}$ ). The potential energy plot shows the protein-ligand complex reaches its stability close to $460 \mathrm{ps}$ (Figure 2d). Overview of this study is presented in Figure 3. At the end of the simulation period, the complex undergoes minor conformational changes and attains its stability.

\section{CONCLUSION}

The results obtained from the present work shows that the bioactive compounds from marine algal sources also play a vital role in interacting with Human papilloma virus (HPV 16) which causes oral and cervical cancers in humans. Our results suggest that Salicylihalamide B from Haliclona species (sponge) obeyed all the rules of virtual screening and can precisely bind to the active pocket of the E6 protein with better conformational stability. Hence, Salicylihalamide B can be proposed as the potent bioactive compound against target E6 of HPV16 and may be furthermore explored as an anticancer drug. Along with potential anti-tumor property, in this study, Salicylihalamide B may conceivably be considered to have the capability of anticancer property.

Table 4: Binding energy and interacting residues of selected bioactive compounds with E6 protein.

\begin{tabular}{cccc}
\hline S. No. & Ligands & $\begin{array}{c}\text { Binding } \\
\text { Energy* }\end{array}$ & $\begin{array}{c}\text { Binding site residues involved in } \\
\text { interactions }\end{array}$ \\
\hline 1 & Ascorbic acid & -3.82 & LEU110, LEU99, ASP49, LYS115 \\
2 & Frigocyclinone & -8.01 & TRP132, LEU100 \\
3 & Salicylihalimide A & -8.76 & ARG102, CYS51 \\
4 & Salicylihalimide B & -8.92 & ARG102, CYS51 \\
\hline
\end{tabular}

*Kcal/mol.

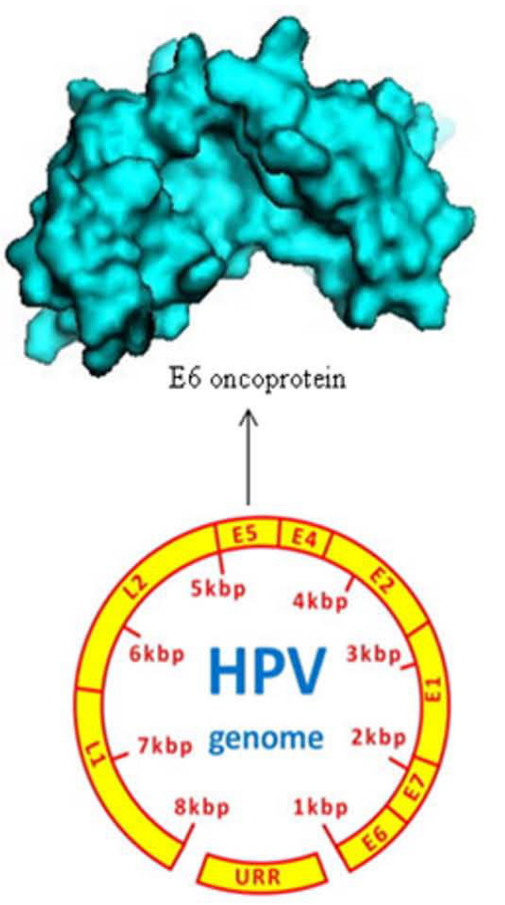

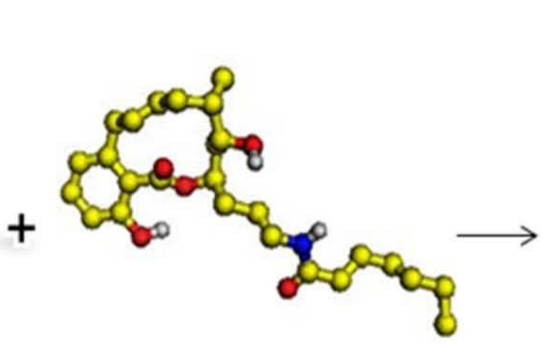

Salicylihalamide B
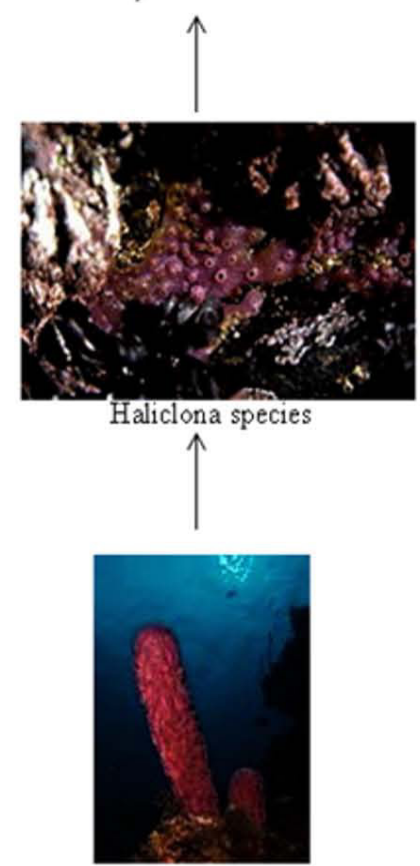

Marine sponge

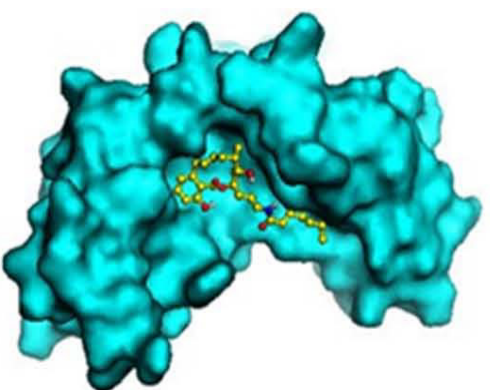

E6-Salicylihalamide B complex<smiles>C1CCCCC1</smiles>

Along with its various
characteristics, in this study this complex acts as a potent anticancer compound against $\mathrm{HPV}$ 16 and inhibits cervical cancer

Fig. 3: Overview of this study. 


\section{ACKNOWLEDGMENT}

We thank Vellore Institute of Technology University for the Computational facility.

\section{REFERENCES}

Adams C, Naturopath. Red Algae Extract Treats Ebola - and HIV, SARS and HCV. PLoS ONE. 2013; 8(5).

Alcaraz MJ, Payá M. Marine sponge metabolites for the control of inflammatory diseases. Current Opinion in Investigational Drugs. 2006; 7:974-979.

Aoki S, Kong D, Matsui K, Rachmat R, Kobayashi M. Sesquiterpene Aminoquinones, from a Marine Sponge, Induce Erythroid Differentiation in Human Chronic Myelogenous Leukemia, K562 Cells. Chemical and Pharmaceutical Bulletin. 2004; 52(8):935-937.

Apt KE, Clendennen SK, Powers DA, Grossman AR. The gene family encoding the fucoxanthin chlorophyll proteins from the brown alga Macrocystis pyrifera. Molecular and general genetics MGG. 1995; 246(4):455-464.

Arumugam M, Lulu S, Kumari S, Kumari NVD. Computational screening and evaluation of bioactive compounds against NS3 helicase of HCV. International Journal of Pharmacy and Pharmaceutical Sciences 2013; 5(4):370-376.

Asgharpour M, Rodgers B, Hestekin JA. Eicosapentaenoic Acid from Porphyridium Cruentum: Increasing Growth and Productivity of Microalgae for Pharmaceutical Products. Energies. 2015; 8:10487-10503.

Domozych DS, Cianci M, Fangel JU, Mikkelsen MD, Ulvskov P, Willats WGT. The cell walls of green algae: a journey through evolution and diversity. Frontiers in plant science 2012; 3:1-7.

Francavilla M, Colaianna, Zotti M, Morgese MG, Trotta P, Tucci $\mathrm{P}$, Schiavone S, Cuomo V, Trabace L. Extraction, characterization and in vivo neuromodulatory activity of phytosterols from microalga Dunaliella tertiolecta. Current Medicinal Chemistry. 2012; 19(18):3058-67.

García-Vilas JA, Martínez-Poveda B, Quesada AR, Medina MA. Aeroplysinin-1, a Sponge-Derived Multi-Targeted Bioactive Marine Drug. Marine Drugs. 2016; 14(1):1-12.

Ghose AK, Viswanadhan VN, Wendoloski JJ. A knowledgebased approach in designing combinatorial or medicinal chemistry libraries for drug discovery. Journal of Combinatorial Chemistry 1999; 1(1):55-68.

Gordaliza M. Cytotoxic terpene quinones from marine sponges. Marine Drugs. 2010; 8:2849-2870.

Groniger A, Sinha RP, Klisch M, Hader D-P. Photoprotective compounds in cyanobacteria, phytoplankton and macroalgae - A database. Journal of Photochemistry and Photobiology B: Biology. 2000; 5:15-122.

Gupta S, Abu-Ghannam N. Bioactive potential and possible health effects of edible brown seaweeds. Trends in Food Science \& Technology. 2011; 1-12.

Hartog K, Intern RJD. Bioactive Compounds Derived from Marine Algal Species. Journal of Phycology. 1999; 35.2:215-226.

Hoory T, Monie A, Gravitt P, Wu TC. Molecular Epidemiology of Human Papillomavirus. Journal of the Formosan Medical Association 2008; 107(3):198-217.

Huibregtse JM, Scheffner M, Howley PM. A cellular protein mediates association of $\mathrm{p} 53$ with the E6 oncoprotein of human papillomavirus types 16 or 18. The EMBO Journal. 1991; 10:4129-4135.

Huibregtse JM, Scheffner M, Howley PM. Cloning and expression of the cDNA for E6-AP, a protein that mediates the interaction of the human papillomavirus E6 oncoprotein with p53. Molecular and Cellular Biology. 1993a; 13:775-784.

Huibregtse JM, Scheffner M, Howley PM. Localization of the E6-AP regions that direct human papillomavirus E6 binding, association with $\mathrm{p} 53$, and ubiquitination of associated proteins. Molecular and Cellular Biology. 1993b; 13:4918-4927.

Husain E, Prowse DM, Ktori E, Shaikh T, Yagoob M, Junaid I, Baithun S. Human papillomavirus is detected in transitional cell carcinoma arising in renal transplant recipients. Pathology. 2009; 41(3):245-7.
Isbrucker RA, Cummins J, Pomponi SA, Longley RE, Wright AE. Tubulin polymerizing activity of dictyostatin-1, a polyketide of marine sponge origin. Biochemical Pharmacology. 2003; 66(1):75-82.

Jiao G, Yu G, Zhang J, Ewart HS. Chemical Structures and Bioactivities of Sulfated Polysaccharides from Marine Algae. Marine Drugs. 2011; 9:196-223.

Jimenez JT, Šturdíková M, Šturdík E. Natural products of marine origin and their perspectives in the discovery of new anticancer drugs. Acta Chimica Slovaca 2009; 2(2):63-74.

Kakinuma M, Park CS, Amano H. Distribution of free L-cysteine and glutathione in seaweeds. Fisheries science. 2001; 67:194-196.

Karsten U, Sawall T, Hanelt D, Bischof K, Figueroa FL, Moya A-F, Wiencke C. An inventory of UV-absorbing mycosporine-like amino acids in macroalgae from polar to warm temperate regions. Botanica Marina. 1998; 41:443-453.

Krohn K. Dictionary of Marine Natural Products with CDROM, JW Blunt, MHG. Munro (Eds.). CRC Press Book 2007; 993-1184.

Ledwaba T, Dlamini Z, Naicker S, Bhoola K. Molecular genetics of human cervical cancer: role of papillomavirus and the apoptotic cascade. Biological Chemistry. 2004; 385:671-682.

Li N, Yang L, Zhang Y, Zhao P, Zheng T, Dai M. Human papillomavirus infection and bladder cancer risk: A meta-analysis. The Journal of Infectious Diseases. 2011; 204(2):217-223.

Liyanage SS, Segelov E, Garland SM, Tabrizi SN, Seale H, Crowe PJ, Dwyer DE, Barbour A, Newall AT, Malik A, Macintyre CR. Role of human papillomaviruses in esophageal squamous cell carcinoma. Asia Pacific Journal of Clinical Oncology. 2013; 9:12-28.

Manam RR, Teisan S, White DJ, Nicholson B, Grodberg J, Neuteboom ST, Lam KS, Mosca DA, Llyod GK, Potts BC. Lajollamycin, a Nitro-tetraene Spiro-â-lactone- $\gamma$-lactam Antibiotic from the Marine Actinomycete Streptomyces nodosus. Journal of Natural Products. 2005; 68(2):240-243.

Michalak I, Chojnacka K. Algae as production systems of bioactive compounds. Engineering in Life Sciences. 2015; 15:160-176.

Michiels J, Skrivanova E, Missotten J, Ovyn A, Mrazek J, Smet DS, Dierick N. Intact brown seaweed (Ascophyllum nodosum) in diets of weaned piglets: effects on performance, gut bacteria and morphology and plasma oxidative status. Journal of Animal Physiology and Animal Nutrition. 2011; 1-11.

Molinski TF, Dalisay DS, Lievens SL, Sludes JP. Drug development from marine natural products. Nature Reviews Drug Discovery. 2009; 8(1):69-85.

Morris GM, Huey R, Lindstrom W, Sanner MF, Belew RK, Goodsell DS, Olson AJ. Autodock4 and AutoDockTools4: Automated Docking with Selective Receptor Flexibility. Journal of Computational Chemistry. 2009; 30:2785-2791.

Munger K, Baldwin A, Edwards KM, Hayakawa H, Nguyen CL, Owens M, Grace M, Huh K. Mechanisms of human papillomavirusinduced oncogenesis. Journal of Virology. 2004; 78:11451-11460.

Murakami N, Sugimoto M, Morita M, Kobayashi M. Total Synthesis of Agosterol A: An MDR-Modulator from a Marine Sponge. Chemistry- A European Journal. 2001; 7(12):2663-2670.

O’Boyle NM, Banck M, James CA, Morley C, Vandermeersch T, Hutchison GR. Open Babel: An open chemical toolbox. Journal of cheminformatics. 2011; 3:33.

Oliveira ALLD, Felicio RD, Debonsi HM. Marine natural products: chemical and biological potential of seaweeds and their endophytic fungi. Revista Brasileira de Farmacognosia. 2012; 22(4):906-920.

Pal A, Kamthania MC, Kumar A. Bioactive Compounds and Properties of Seaweeds-A Review. Open Access Library Journal. 2014, $1: \mathrm{e} 752$.

Panayotova V, Stancheva M, Dobreva D. Alpha-tocopherol and ergocalciferol contents of some macroalgae from Bulgarian Black Sea coast. Ovidius University Annals of Chemistry. 2013; 24(1):13-16.

Patel D, Huang SM, Baglia LA, McCance DJ. The E6 protein of human papillomavirus type 16 binds to and inhibits co-activation by $\mathrm{CBP}$ 
and p300. The EMBO Journal. 1999; 18(18):5061-5072.

Perdicaris S, Vlachogianni T, Valavanidis A. Bioactive Natural Substances from Marine Sponges: New Developments and Prospects for Future Pharmaceuticals. Natural Products Chemistry and Research. 2013; 1(3):114

Pereira H, Barreira L, Figueiredo F, Custodio L, Duarte C-V, Polo C, Resek E, Engelen A, Varela J. Polyunsaturated Fatty Acids of Marine Macroalgae: Potential for Nutritional and Pharmaceutical Applications. Marine Drugs. 2012; 10:1920-1935.

Plaza M, Santoyo S, Jaime L, Reina G-BG, Herrero M, Senorans, FJ, Ibanez E. Screening for bioactive compounds from algae. Journal of Pharmaceutical and Biomedical Analysis. 2010; 51:450-455.

Ponder J, Yoo BH, Abraham AD, Li Q, Ashley AK, Amerin CL, Zhou Q, Reid BG, Reigan P, Hromas R, Nickoloff JA, LaBarbera DV. Neoamphimedine Circumvents Metnase-Enhanced DNA Topoisomerase II $\alpha$ Activity Through ATP-Competitive Inhibition. Mar. Drugs. 2011; 9:2397-2408.

Saeidnia S, Manayi A, Gohari AR, Abdollahi M. The Story of Beta-sitosterol- A Review. European Journal of Medicinal Plants. 2014; 4(5):590-609.

Sajilata MG, Singhal RS, Kamat MY. The Carotenoid Pigment Zeaxanthin-A Review. Comprehensive Reviews in Food Science and Food Safety. 2008; 7:29-49.

Schuler LD, Daura X, Gunsteren WFV. An improved GROMOS96 force field for aliphatic hydrocarbons in the condensed phase. Journal of Computational Chemistry. 2001; 22:1205-1218.

Schüttelkopf AW, Aalten DMV. PRODRG: A tool for high-throughput Crystallography of protein-ligand complexes. Acta Crystallographica. 2004; D60:1355-1363.

Simmons TL, Andrianasolo E, McPhail K, Flatt P, Gerwick WH. Marine natural products as anticancer drugs. Molecular Cancer
Therapeutics. 2005; 4(2):333-342.

Sipkema D, Franssen MC, Osinga R, Tramper J, Wijffells RH. Marine sponges as pharmacy. Marine Biotechnology. 2005; 7:142-162.

Sundarrajan S, Kumari S, Lulu S, Arumugam M. Identification of Potent Hepatitis C Virus RdRp Inhibitors by Structure Based Drug Designing. BMR Bioinformatics \& Cheminformatics. 2014; 1(1):1-14.

Thomas M, Pim D, Banks L. The role of the E6-p53 interaction in the molecular pathogenesis of HPV. Oncogene. 1999; 18:7690-7700.

Tungteakkhun SS, Duerksen-Hughes PJ. Cellular binding partners of the human papillomavirus E6 protein. Archives of Virology. 2008; 153(3):397-408.

White EA, Kramer RE, Tan MJ, Hayes SD, Harper JW, Howley PM. Comprehensive Analysis of Host Cellular Interactions with Human Papillomavirus E6 Proteins Identifies New E6 Binding Partners and Reflects Viral Diversity. Journal of Virology. 2012; 86:13174-13186.

Yu M-H, Glazer AN, Spencer KG, West JA. Phycoerythrins of the Red Alga Calliithamnion- Variation in Phycoerythrobilin and Phycourobilin content. Plant Physiology. 1981; 68(2):482-488.

Rietz A, Petrov DP, Bartolowits M, DeSmet M, Davisson VJ, Androphy EJ. Molecular Probing of the HPV-16 E6 Protein Alpha Helix Binding Groove with Small Molecule Inhibitors. PLoS ONE. 2016; 11(2):1-20.

How to cite this article:

Dhamodharan P, Ponnusamy N, Odumpatta R, Lulu S, Arumugam M. Computational investigation of marine bioactive compounds against E6 oncoprotein of Human Papilloma VirusHPV16. J App Pharm Sci, 2018; 8(04): 023-032. 